\title{
Weevils in pasture: a comparison of sampling techniques
}

\author{
M.R. McNeill and C. van Koten \\ AgResearch, Private Bag 4749, Christchurch 8140, New Zealand \\ Corresponding author: mark.mcneill@agresearch.co.nz
}

This study compared four methods to quantitatively sample adult Listronotus bonariensis and Sitona lepidus (both Coleoptera: Curculionidae) in dairy pasture, with a view of determining an appropriate sampling method for accurate population estimation in terms of weevils $/ \mathrm{m}^{2}$. Collections were made by one of three vacuum methods: a vacuum cleaner to take $12 \times 0.2 \mathrm{~m}^{2}$ quadrats, a Vortis $(24 \times 16 \mathrm{~cm}$ diameter, $\left.0.02 \mathrm{~m}^{2}\right)$ or blower-vac $\left(30 \mathrm{~m} \times \mathrm{ca} 11 \mathrm{~cm}\right.$ diameter, $\left.3.27 \mathrm{~m}^{2}\right)$ to suck the weevils from the soil surface; or by taking turf cores $\left(48 \times 10 \mathrm{~cm}\right.$ diameter, $\left.0.00785 \mathrm{~m}^{2}\right)$ with extraction of weevils using a Berlesse funnel. The sampling was carried out on three occasions and the four methods compared for each occasion. Overall, for both weevil species, coring or the vacuum cleaner generally indicated significantly higher densities compared to the Vortis or blower vac, and are concluded to be the most accurate methods for measuring adult density. However, the blower-vac is a convenient tool for mass collection of weevils and parasitoids, while the Vortis is useful for monitoring more fragile insects such as Hymenoptera.

\section{Argentine stem weevil and golf: being a pest in turf grasses}

\author{
P.J. Vittum ${ }^{1}$ and M.R. McNeill ${ }^{2}$ \\ ${ }^{1}$ University of Massachusetts, Department of Plant, Soil, and Insect Sciences, Amherst, \\ Massachusetts, USA \\ ${ }^{2}$ AgResearch Lincoln, Private Bag 4749, Christchurch 8140, New Zealand \\ Corresponding author: pvittum@ent.umass.edu
}

Argentine stem weevil (ASW), Listronotus bonariensis, is a well known pest of grass species in New Zealand pasture. Less well known is its pest status in amenity turf, especially golf courses, in New Zealand and Australia. ASW infests Poa annua and browntop, which are common grasses on New Zealand golf courses. Larval damage initially appears as chlorotic turf, then turns straw-coloured, which can be confused as dormant (dry) or diseased turf. While many aspects of the biology of ASW in pasture have been elucidated, little is known about the biology or behaviour of the insect on golf courses. A preliminary study was carried out from mid September 2010 to early February 2011 at Pleasant Point Golf Club (South Canterbury), where ASW has caused significant damage in recent years. The study looked at the relative number of ASW adults collected from the fairway and rough and their reproductive condition. The study also tracked the presence and stage of development of larvae in the fairway throughout the season. An insecticide efficacy trial that included treatments targeting adults or larvae of the second summer generation showed excellent $(>85 \%)$ control with a single application of an adulticide or larvicide in December or early-January. 